\title{
Penerapan Model Pembelajaran Berbasis Masalah Menggunakan Asesmen Ranking Task Exercise (RTE) terhadap Pemahaman Konsep Hukum Newton
}

\author{
Eko Muhtar Syafaat, Nurjannah, dan I Komang Werdhiana \\ Email: ekomuhtar@ymail.com \\ Program Studi Pendidikan Fisika, Jurusan Pendidikan MIPA, Universitas Tadulako, \\ Jl. Soekarno Hatta KM. 9 Kampus Bumi Tadulako Tondo Palu - Sulawesi Tengah
}

\begin{abstract}
Abstrak- Penelitian ini bertujuan untuk mengetahui peningkatan pemahaman konsep melalui penerapan model pembelajaran berbasis masalah menggunakan asesmen Rangking Task Exercise (RTE) pada materi hukum Newton kelas X IPA SMA Negeri 5 Palu. Metode yang digunakan adalah eksperimen kuasi dengan Nonequivalent control group design. Populasi penelitian ini adalah seluruh siswa kelas X IPA SMA Negeri 5 Palu. Teknik pengambilan sampel adalah purposive sampling. Kelas X IPA 2 sebagai kelas eksperimen dan kelas X IPA 4 sebagai kelas kontrol. Instrumen pemahaman konsep berupa tes pilihan ganda yang telah divalidasi oleh validator. Peningkatan rata-rata $\mathrm{N}$-gain yang mengikuti model pembelajaran berbasis masalah menggunakan latihan RTE adalah 33,64\% dan peningkatan rata-rata yang mengikuti model pembelajaran berbasis masalah menggunakan lembar kerja kelompok adalah $40,04 \%$. Analisis data menggunakan uji prasyarat normalitas dan homogenitas dengan uji-t pada taraf signifikansi $5 \%$ dan $\mathrm{dk}=64$. Hasil perhitungan statistik dari pengujian hipotesis menggunakan uji-t didapatkan harga $t$ hitung sebesar 0,35 dan $t$ tabel pada taraf signifikansi $5 \%$ dan $d k=64$ adalah 1,99. Disimpulkan bahwa tidak terdapat peningkatan pemahaman konsep secara signifikan melalui penerapan model pembelajaran berbasis masalah menggunakan asesmen RTE pada materi hukum Newton pada kelas X IPA SMA Negeri 5 Palu.
\end{abstract}

Kata Kunci: pembelajaran berbasis masalah; ranking task exercise (rte); pemahaman konsep.

\section{PENDAHULUAN}

Selama ini sebagian besar bahkan hampir setiap orang, khususnya para siswa menganggap bahwa fisika itu adalah pelajaran yang sangat menakutkan yang dipenuhi dengan rumus-rumus sehingga membuat siswa kurang termotivasi untuk mempelajarinya apalagi untuk memahaminya. Kesulitan yang dialami oleh siswa sehingga tingkat pengetahuan tentang fisika rendah antara lain adalah siswa tidak mengerti tentang apa yang dipelajarinya. Penyebab kesulitan ini, karena konsep-konsep fisika yang abstrak dan bagaimana cara konsepkonsep itu diajarkan. Pemahaman suatu konsep sangat penting untuk menghadapi permasalahan-permasalahan yang berkaitan dengan konsep tersebut. Tanpa adanya pemahaman suatu konsep yang terkait maka permasalahan akan sulit untuk diselesaikan.

Salah satu materi yang sulit untuk dipahami oleh siswa adalah materi tentang hukum Newton. Hukum Newton merupakan konsep dasar yang mempelajari tentang gaya yang memiliki tingkat kompleksitas yang tinggi sehingga siswa merasa kesulitan untuk memahami bahkan salah konsep. Kesulitan siswa dalam memahami materi ini antara lain yaitu bagaimana cara menentukan arah gaya-gaya yang bekerja pada suatu benda, menentukan percepatan benda yang dihubungkan dengan tali ke arah mendatar, melalui katrol, dll. Sehingga perlu adanya cara untuk membuat siswa termotivasi untuk belajar dengan aktif agar konsep materi ini dapat dipahami dan di serap oleh siswa dengan baik.

Dalam dunia pendidikan saat ini, telah banyak dikenal berbagai macam pendekatan dan modelmodel pembelajaran yang bertujuan untuk meningkatkan pemahaman konsep. Salah satu model pembelajaran tersebut adalah model pembelajaran berbasis masalah. Model pembelajaran berbasis masalah dapat meningkatkan pemahaman tentang materi yang diajarkan dan siswa diharapkan dapat 
menerapkannya dalam kehidupan sehari-hari [3]. Menurut Ward [3], model pembelajaran ini melibatkan siswa dalam memecahkan masalah melalui metode ilmiah sehingga siswa dapat mempelajari pengetahuan yang berhubungan dengan masalah tersebut dan sekaligus melatih keterampilan dalam memecahkan suatu masalah.

Menurut Adnyani [1] bahwa penerapan model pembelajaran berbasis masalah dapat meningkatkan pemahaman belajar siswa. Hasil penelitiannya menunjukkan adanya peningkatan pemahaman konsep yang signifikan terhadap materi yang telah diajarkan. Jika pembelajaran dimulai dengan suatu permasalahan yang bersifat kontekstual maka akan terjadi ketidakseimbangan kognitif pada diri siswa, sehingga akan muncul pertanyaan-pertanyaan dan keadaan ini dapat mendorong rasa keingintahuannya terhadap materi tersebut.

Cara lain untuk menumbuhkan pemahaman konsep siswa adalah dengan memberikan latihan-latihan soal atau suatu instrumen yang dapat mengasah kemampuan konsep fisika siswa. Instrumen yang biasa dikenal dan dihadapi oleh siswa untuk mengukur tingkat pengetahuannya adalah tes esai dan pilihan ganda. Namun masih banyak cara untuk mengukur tingkat pengetahuan dan pemahaman konsep siswa. Menurut O'Kuma et al. [5] Rangking Task Exercise (RTE) dapat meningkatkan pemahaman konsep dan mengukur kemampuan konsep siswa. RTE merupakan instrumen tes yang memiliki empat komponen dasar yakni deskripsi sebuah situasi termasuk cara untuk merangkingnya (mengurutkan); menunjukan beberapa gambar yang hampir sama dengan keadaan yang berbeda untuk dibandingkan dan menjelaskan alasan mengapa siswa menjawab seperti itu. Selain untuk menilai sejauh mana siswa dalam memahami materi yang telah diajarkan, instrumen ini juga dapat menumbuhkan kemampuan siswa menganalisis dan memahami konsep-konsep fisika siswa.

Hasil penelitian yang dilakukan oleh Amalia [2] menunjukkan bahwa Rangking Task Exercise
ISSN 23383240

(RTE) dapat meningkatkan kemampuan analisis siswa dan dapat memecahkan suatu masalah. Hal ini diperkuat dengan data-data yang diperoleh yaitu saat siswa diberikan tes awal skor rata-rata yang diperoleh yaitu 41,71 sedangkan pada skor tes akhir skor rata-ratanya meningkat menjadi 74,10. Hal ini menunjukkan bahwa siswa setelah diberi latihan menggunakan Rangking Task Exercise (RTE), tingkat pemahaman konsep pada materi yang diajarkannya meningkat. Seperti yang telah dinyatakan oleh O'Kuma et al. [5] bahwa Rangking Task Exercise (RTE) baik untuk dijadikan tugas dalam kelas maupun tugas rumah untuk dapat meningkatkan pemahaman konsep siswa.

Berdasarkan hal tersebut bahwa untuk meningkatkan kemampuan pemahaman konsep fisika siswa khususnya pada materi hukum Newton dapat menerapkan model pembelajaran yang dapat membuat siswa memahami materi tersebut, karena dengan menerapkan model pembelajaran yang dapat mengubah cara berfikir siswa terhadap masalah sehari-hari maka siswa akan lebih cepat memahaminya. Model pembelajaran itu adalah model pembelajaran berbasis masalah dan didukung oleh instrumen yang dapat membantu siswa untuk mengasah kemampuan pemahaman konsep hukum Newton yaitu Rangking Task Exercise (RTE). Maka peneliti melakukan penelitian mengenai pemahaman konsep hukum Newton dalam model pembelajaran berbasis masalah dan disertai oleh latihan Rangking Task Exercise (RTE).

\section{METODELOGI PENELITIAN}

Jenis penelitian yang digunakan adalah jenis penelitian eksperimen kuasi. Adapun populasi pada penelitian ini adalah seluruh siswa kelas $X$ IPA SMA Negeri 5 Palu tahun ajaran 2013/2014 yang tersebar dalam 4 kelas. Kelas $X$ IPA 2 sebagai kelas eksperimen yang siswanya mengikuti model pembelajaran berbasis masalah menggunakan latihan RTE dan kelas X IPA 4 sebagai kelas kontrol yang siswanya mengikuti model pembelajaran berbasis masalah menggunakan lembar kerja kelompok. 
Pengambilan sampel pada penelitian ini adalah purposive sampling, yaitu teknik penentuan sampel dengan pertimbangan tertentu dari guru mata pelajaran fisika pada kedua kelas di sekolah tersebut. Kedua kelas yang dipilih merupakan kelas yang dianggap homogen secara akademik. [4]

Data yang diambil dari penelitian ini yaitu pemahaman konsep fisika materi hukum Newton berupa tes pilihan ganda yang diberikan pada awal dan akhir perlakuan. Desain penelitian yang digunakan seperti pada Tabel 1.

TABEL 1. NONEQUIVALENT CONTROL GROUP DESIGN

\begin{tabular}{|l|r|c|c|}
\hline \multicolumn{1}{|c|}{ Kelas } & $\begin{array}{c}\text { Tes } \\
\text { Awal }\end{array}$ & Perlakuan & $\begin{array}{c}\text { Tes } \\
\text { Akhir }\end{array}$ \\
\hline $\begin{array}{l}\text { Kelas Eksperimen } \\
\text { (KE) }\end{array}$ & O1 & X1 & O2 \\
\hline Kelas Kontrol (KK) & O3 & X2 & O4 \\
\hline
\end{tabular}

Keterangan:

KE : Kelas Eksperimen

KK : Kelas Kontrol

O1 dan O3 : Tes Awal (digunakan tes yang sama)

O2 dan O4: Tes Akhir (digunakan tes yang sama)

X1 : Model Pembelajaran Berbasis Masalah Menggunakan Latihan RTE

X2 : Model Pembelajaran Berbasis Masalah Menggunakan Lembar Kerja Kelompok.

\section{HASIL DAN PEMBAHASAN}

Nilai pemahaman konsep hukum Newton siswa diperoleh dari hasil tes awal dan tes akhir yang dilakukan pada kedua kelas tersebut. Data hasil pemahaman konsep hukum Newton siswa diperoleh seperti pada Tabel 2.

TABEL 2. NILAI HASIL TES PEMAHAMAN KONSEP PADA TES AWAL DAN TES AKHIR

\begin{tabular}{|l|c|c|c|c|}
\hline \multirow{2}{*}{ Nilai } & \multicolumn{2}{|c|}{ Tes Awal } & \multicolumn{2}{c|}{ Tes Akhir } \\
\cline { 2 - 5 } & $\begin{array}{c}\text { Kelas } \\
\text { Eksp. }\end{array}$ & $\begin{array}{l}\text { Kelas } \\
\text { Kont. }\end{array}$ & $\begin{array}{l}\text { Kelas } \\
\text { Eksp. }\end{array}$ & $\begin{array}{l}\text { Kelas } \\
\text { Kont. }\end{array}$ \\
\hline Minimum & 16 & 16 & 28 & 28 \\
\hline Maksimum & 44 & 44 & 52 & 48 \\
\hline Rata-rata & 29,29 & 30,43 & 40,34 & 39,79 \\
\hline $\begin{array}{l}\text { Simpangan } \\
\text { Baku }\end{array}$ & 8,16 & 6,79 & 7,02 & 5,92 \\
\hline
\end{tabular}

ISSN 23383240

Pengujian hipotesis menggunakan Uji t yaitu untuk mengetahui perbedaan peningkatan pemahaman konsep antara kelas eksperimen dan kelas kontrol, dan uji N-Gain digunakan untuk melihat peningkatan pemahaman konsep masing-masing kelas dari tes awal ke tes akhir.

Syarat untuk melakukan uji $t$, data harus terdistribusi normal dan homogen. Uji normalitas digunakan untuk menentukan apakah tingkat pemahaman konsep hukum Newton masingmasing kelas terdistribusi normal atau tidak. Hasil uji normalitas tes akhir kelas eksperimen adalah $\chi^{2}$ hitung $=5,35$ dan kelas kontrol adalah $\chi^{2}$ hitung $=4,53$ sedangkan $\chi^{2}$ tabel $=7,81$. Syarat bahwa data terdistribusi normal adalah $\chi^{2}$ hitung < $\chi^{2}$ tabel, sehingga dapat disimpulkan bahwa data kelas eksperimen dan kelas kontrol terdistribusi normal. Uji homogenitas digunakan untuk melihat data yang diperoleh dari kedua kelas apakah bersifat homogen. Perolehan uji homogenitas tes akhir kelas eksperimen dan kelas kontrol pada taraf signifikansi $\alpha=0,05$ adalah $F$ hitung $=1,40$ dan $F$ tabel $=1,80$. Syarat data bersifat homogen adalah $\mathrm{F}$ hitung < $\mathrm{F}$ tabel, sehingga dapat disimpulkan bahwa data kedua kelas berasal dari varians yang sama (homogen).

Hasil uji hipotesis tes akhir kelas eksperimen dan kelas kontrol menunjukkan $\mathrm{t}$ hitung $<\mathrm{t}$ tabel yaitu $\mathrm{t}$ hitung $=0,35$ dan $\mathrm{t}$ tabel $=1,99$, maka $\mathrm{H}_{0}$ diterima. Sehingga dapat disimpulkan bahwa pemahaman konsep melalui penerapan model pembelajaran berbasis masalah dengan menggunakan asesmen RTE pada materi hukum Newton, sama dengan pemahaman konsep melalui penerapan model pembelajaran berbasis masalah menggunakan lembar kerja kelompok.

Nilai rata-rata hasil uji peningkatan pemahaman konsep pada kelas eksperimen yaitu 33,64 dan kelas kontrol yaitu 40,04, menunjukan bahwa rata-rata peningkatan pemahaman konsep materi hukum Newton kedua kelas berada pada kriteria $30 \leq \mathrm{g}<70$ yaitu sedang.

Penelitian ini bertujuan untuk meningkatkan pemahaman konsep siswa melalui model pembelajaran berbasis masalah menggunakan 
latihan RTE pada materi hukum Newton. Model pembelajaran berbasis masalah merupakan model pembelajaran yang menuntut siswa agar dapat memahami suatu konsep, prinsip dan keterampilan melalui suatu masalah yang disajikan pada proses pembelajaran. Masalah yang digunakan pada model pembelajaran ini berupa latihan RTE yang menurut siswa latihan ini merupakan latihan yang baru mereka dapatkan. Latihan RTE merupakan latihan yang memberikan beberapa gambar yang membutuhkan analisis untuk mengurutkannya dan memberikan alasan mengapa mengurutkan gambar seperti itu.

Pengujian hipotesis yang digunakan merupakan uji-t 1 pihak, adapun alasan menggunakan uji-t 1 pihak ini disebabkan adanya data yang mendukung mengenai arah kecenderungan dari suatu hipotesis. Data yang diperoleh menyatakan bahwa model pembelajaran berbasis masalah dan latihan RTE dapat meningkatkan pemahaman konsep siswa. Hal ini diperoleh dari data penelitian sebelumnya yang telah dipaparkan dilatar belakang penelitian ini. Penelitian yang dilakukan oleh Gustina [4] menunjukkan bahwa model pembelajaran berbasis masalah dapat meningkatkan pemahaman konsep fisika secara signifikan. Penelitian ini juga dilakukan oleh Dasna [3] dan Adnyani [1] bahwa model pembelajaran berbasis masalah dapat memecahkan masalah dan meningkatkan pemahaman konsep siswa. O'Kuma et al. [5] menyatakan RTE dapat meningkatkan pemahaman konsep dan mengukur kemampuan konsep siswa. Menurut Amalia [2] dalam penelitiannya juga menunjukkan bahwa tingkat pemahaman konsep siswa meningkat setelah diberi latihan menggunakan RTE. Sehingga model pembelajaran berbasis masalah dan latihan RTE digabungkan dalam satu penelitian, namun dari hasil uji-t 1 pihak menunjukan bahwa penerapan model pembelajaran berbasis masalah mengunakan latihan RTE tidak dapat meningkatkan pemahaman konsep secara signifikan.
ISSN 23383240

Hasil dari rerata $\mathrm{N}$-gain menunjukan bahwa ada peningkatan pemahaman konsep hukum Newton di kedua kelas namun peningkatannya berada pada kriteria sedang sehingga hasil uji-t menunjukkan tidak ada perbedaan peningkatan pemahaman konsep antara kelas eksperimen dan kelas kontrol.

Pemahaman konsep melalui model pembelajaran berbasis masalah menggunakan latihan RTE pada kelas eksperimen sama dengan peningkatan pemahaman konsep melalui model pembelajaran berbasis masalah menggunakan latihan lembar kerja kelompok pada kelas kontrol disebabkan oleh beberapa faktor. Faktor yang pertama yaitu pada kelas eksperimen dan kelas kontrol diterapkan model pembelajaran yang sama. Digunakannya model pembelajaran yang sama di kedua kelas karena pertimbangan bila kelas eksperimen diberikan dua jenis perlakuan yaitu model pembelajaran berbasis masalah dan latihan RTE untuk meningkatkan pemahaman konsep siswa sedangkan kelas kontrol hanya menggunakan model pembelajaran konvensional sudah tentu kelas eksperimen yang akan lebih meningkat pemahaman konsepnya karena dari data penelitian-penelitian sebelumnya menyatakan bahwa model pembelajaran berbasis masalah dapat meningkatkan pemahaman konsep siswa dan latihan RTE juga dapat meningkatkan pemahaman siswa. Faktor yang kedua adalah bentuk latihan yang diberikan pada siswa ketika proses pembelajaran berlangsung. Untuk memperoleh informasi mengenai latihan RTE yang diberikan pada kelas eksperimen maka dibuatlah latihan yang tingkat kesulitannya menyerupai latihan RTE agar siswa kelas kontrol memperoleh pengalaman belajar yang sama dengan kelas eksperimen. Latihan tersebut merupakan lembar kerja kelompok yang mempunyai tingkat kesukaran yang hampir sama dengan latihan RTE, sehingga latihan lembar kerja kelompok ini dapat menjadi pembanding latihan RTE yang di berikan pada siswa kelas eksperimen.

Latihan RTE dikalangan siswa SMAN 5 palu merupakan latihan pembelajaran yang baru 
mereka dapatkan sehingga pada pertemuan pertama siswa merasa kesulitan dalam menghadapi latihan yang diberikan. Namun, setelah diberikan petunjuk dalam memecahkan masalah siswa baru mengerti bagaimana cara menyelesaikan masalah yang ada pada latihan tersebut, sedangkan pada latihan lembar kerja kelompok yang diberikan pada kelas kontrol merupakan jenis latihan yang biasa mereka hadapi sehingga siswa sudah mengerti bagaimana cara menyelesaikannya. Inilah faktor ketiga yang menyebabkan kedua kelas tidak ada perbedaan peningkatan pemahaman konsep pada materi hukum Newton. Faktor yang keempat adalah waktu pembelajaran yang sangat kurang jika diterapkannya model pembelajaran berbasis masalah menggunakan latihan RTE pada proses pembelajaran. Model pembelajaran berbasis masalah merupakan model pembelajaran dengan fase-fase pembelajaran yang cukup lama, seperti yang dikatakan oleh Adnyani [1] bahwa model pembelajaran berbasis masalah dapat meningkatkan hasil belajar siswa namun dalam proses pembelajarannya membutuhkan waktu yang lama sehingga dapat menyita waktu jam pelajaran lain. Latihan RTE juga, untuk menyelesaikan permasalahannya membutuhkan waktu yang lama, sehingga dalam proses pembelajaran pada pertemuan pertama tidak berjalan dengan maksimal. Latihan RTE yang diberikan untuk setiap pertemuan adalah 5 soal latihan yang harus di kerjakan oleh setiap kelompok, namun siswa tidak dapat menyelesaikannya dengan waktu yang telah ditentukan, sehingga pada pertemuan kedua dan ketiga, setiap kelompok harus menjawab soal sesuai dengan nomor urut kelompoknya dan jika ada kelompok yang telah selesai sebelum tiba waktu yang telah ditentukan maka kelompok tersebut dapat mengerjakan permasalahan yang lainnya dalam latihan tersebut. Berbeda dengan siswa pada kelas kontrol, setiap kelompok harus mengerjakan semua permasalahan yang ada pada lembar kerja kelompok.

\section{KESIMPULAN}

Berdasarkan hasil penelitian dan analisis data hasil penelitian, maka dapat disimpulkan bahwa tidak terdapat peningkatan pemahaman konsep secara signifikan melalui penerapan model pembelajaran berbasis masalah menggunakan asesmen RTE dan lembar kerja kelompok.

\section{DAFTAR PUSTAKA}

[1] Adnyani, Putu Sri. 2010. Penerapan Model Pembelajaran Berbasis Masalah Melalui Metode Pemberian Tugas untuk Meningkatkan Pemahaman Belajar fisika Pada Siswa Kelas Xa SMA Negeri I Dampelas.Skripsi tidak diterbitkan. Palu. FKIP. Universitas Tadulako: tidak diterbitkan.

[2] Amalia, Nurbaiti. 2012. Penerapan Ranking Task Exercise dalam Model Pembelajaran Kooperatif Tipe Think Talk Write untuk Meningkatkan Kemampuan Analisis Siswa, [Online], http://repository.upi.edu. [diakses 12 Desember 2012].

[3] Dasna, I wayan dan Sutrisno. 2007. Pembelajaran Berbasis Masalah.[Online] http://file.upi.edu/Direktori/FPIPS/JUR. PEND. SEJA $\mathrm{RAH}$, [diakses 26 Januari 2013].

[4] Gustina. 2011. Applying Problem Based-Learning Model To Increase Conceptual Understanding of The Students In Physic Class VIII SMP Negeri 10 Palu. Skripsi tidak diterbitkan. Palu. FKIP. Universitas Tadulako: tidak diterbitkan.

[5] O'Kuma, et al. 2004. Rangking Task Exercise in Phisics:Student Edition Instructor's Guide. USA: Upper Saddle River.

[6] Sugiyono. 2010. Metode Penelitian Pendidikan. Bandung: Alfabeta. 